CLINICAL STUDY

\title{
Expression of functional KISS1 and KISS1R system is altered in human pituitary adenomas: evidence for apoptotic action of kisspeptin-10
}

Antonio J Martínez-Fuentes ${ }^{1}$, Marcelo Molina ${ }^{1}$, Rafael Vázquez-Martínez ${ }^{1}$, Manuel D Gahete ${ }^{1}$, Luis JiménezReina $^{2}$, Jesús Moreno-Fernández ${ }^{3}$, Pedro Benito-López ${ }^{3}$, Ana Quintero ${ }^{1}$, Andrés de la Riva ${ }^{4}$, Carlos Diéguez ${ }^{5}$, Alfonso Soto ${ }^{6}$, Alfonso Leal-Cerro ${ }^{6}$, Eugenia Resmini ${ }^{7}$, Susan $\mathrm{M} \mathrm{Webb}^{7}$, Maria C Zatelli ${ }^{8}$, Ettore C degli Uberti ${ }^{8}$, María M Malagón ${ }^{1}$, Raul M Luque ${ }^{1}$ and Justo P Castaño ${ }^{1}$

${ }^{1}$ Department of Cell Biology, Physiology and Immunology, Instituto Maimónides de Investigación Biomédica de Córdoba (IMIBIC), and CIBER Fisiopatología de la Obesidad y Nutrición (CIBERobn) and ${ }^{2}$ Department of Morphological Sciences, University of Córdoba, Edificio Severo Ochoa, Planta 3 , Campus de Rabanales, E-14014 Córdoba, Spain, ${ }^{3}$ Service of Endocrinology and Nutrition and ${ }^{4}$ Service of Neurosurgery, Hospital Reina Sofía, Córdoba, Spain, ${ }^{5}$ Department of Physiology, University of Santiago de Compostela, Santiago de Compostela, Spain, ${ }^{6}$ Division of Endocrinology, Virgen del Rocio University Hospital, Sevilla, Spain, ${ }^{7}$ Endocrinology and Medicine Departments and Centro de Investigación Biomédica en Red de Enfermedades Raras (CIBER-ER, Unidad 747), ISCIII, Hospital Sant Pau, Universitat Autònoma de Barcelona, Barcelona, Spain and ${ }^{8}$ Section of Endocrinology, Department of Biomedical Sciences and Advanced Therapies, University of Ferrara, Ferrara, Italy

(Correspondence should be addressed to J P Castaño; Email: justo@uco.es)

\begin{abstract}
Context: KISS1 was originally identified as a metastasis-suppressor gene able to inhibit tumor progression. KISS1 gene products, the kisspeptins, bind to a G-protein-coupled receptor (KISS1R, formerly GPR54), which is highly expressed in placenta, pituitary, and pancreas, whereas KISS1 mRNA is mainly expressed in placenta, hypothalamus, striatum, and pituitary.

Objective and design: KISS1/KISS1R pituitary expression profile, coupled to their anti-tumoral capacities, led us to hypothesize that this system may be involved in the biology of pituitary tumors. To explore this notion, expression levels of KISS1R and KISS1 were evaluated in normal and adenomatous pituitaries. Additionally, functionality of this system was assessed by treating dispersed pituitary adenoma cells in primary culture with kisspeptin-10 and evaluating intracellular calcium kinetics and apoptotic rate.

Results: Both KISS1 and KISS1R were expressed in normal pituitary, whereas this simultaneous expression was frequently lost in pituitary tumors, where diverse patterns of KISS1/KISS1R expression were observed that differed among distinct types of pituitary adenomas. Measurement of calcium kinetics revealed that kisspeptin-10 elicits a remarkable increase in $\left[\mathrm{Ca}^{2+}\right]_{\mathrm{i}}$ in individual cells from four out of the five GH-producing adenomas studied, whereas cells derived from non-functioning pituitary adenomas (NFPA, $n=45$ ) did not respond. In contrast, kisspeptin-10 treatment increased the apoptotic rate in cells derived from both GH-producing and NFPA.

Conclusions: These results provide primary evidence that KISS1 and KISS1R expression can be differentially lost in pituitary tumor subtypes, where this system can exert functional, proapoptotic actions, and thereby offer novel insights to investigate the biology and therapeutic options to treat these tumors.
\end{abstract}

European Journal of Endocrinology 164 355-362

\section{Introduction}

Pituitary adenomas are relatively rare, regularly benign neoplasms, which exhibit a wide range of biological behaviors in terms of hormone production and cell proliferation, and ultimately result from health complications (1). In most instances, early surgical intervention provides the best chance for either the cure or the control of pituitary tumor progression and its side effects (2). To date, medical strategies are strongly dependent on the specific tumor, and the options are limited by the reduced number of effective molecular targets that can be employed. Accordingly, it is of high interest to identify and characterize new molecules that could serve as potential targets for pituitary tumor treatment.

The KISS1 gene encodes a precursor protein that is processed into several related peptides, generically named kisspeptins (3-5), where the major product appears to be a 54-amino acid peptide, named kisspeptin-54 or metastin. In addition, three natural 
peptides of 14-, 11-, and 10-amino acids have been also identified, sharing a common 10-amino acid C-terminal region (5). All kisspeptins have been reported to exhibit a similar affinity and efficacy to bind KISS1R (formerly GPR 54; (5)), a previously orphan receptor mainly expressed in brain, testis, ovary, spinal cord, placenta, and pituitary (4-6). Kisspeptins were originally identified by virtue of their ability to inhibit tumor metastasis in human melanoma cells through KISS1R (6-10), thus their 'metastin' name. However, the kisspeptin/ KISS1R system has recently emerged as an essential player in the neuroendocrine regulation of the reproductive axis, as it was already suggested by the severe hypogonadotropism observed in humans displaying mutated $\operatorname{KISS} 1 R(11,12)$, and in animal models lacking this receptor (12). Available evidence indicates that kisspeptins stimulate gonadotropin secretion primarily through an indirect mechanism involving activation of hypothalamic GNRH release (13). Nevertheless, recent data from our group and others have demonstrated that kisspeptins also act directly upon the pituitary by inducing both $\mathrm{LH}$ and $\mathrm{GH}$ release, possibly explaining the functional significance of the reported presence of KISS1R in the rat pituitary $(14,15)$, jointly with its ligands $(3,5,15)$. These findings prompted us to question whether KISS1 and KISS1R were expressed in the human pituitary and whether they may exert a putative role in the regulation of pituitary tumor behavior and/or progression. To answer these questions, we examined the expression of KISS1/KISS1R system in different pituitary tumors, and evaluated the direct action of kisspeptin-10 on cells from several types of pituitary adenomas by measuring its effects on free cytosolic calcium levels $\left(\left[\mathrm{Ca}^{2+}\right]_{\mathrm{i}}\right)$. Finally, we also evaluated the effect of kisspeptin-10 on apoptosis in cells from non-functioning pituitary adenomas (NFPA) and GH-producing adenomas.

\section{Materials and methods}

The study was carried out in accordance with the Declaration of Helsinki and approved by the University Hospital Ethics Committees participating in this research. Written informed consent was obtained from each patient.

\section{Chemicals}

Unless otherwise indicated, chemical products and tissue culture reagents were purchased from Sigma Chemical Co.

\section{Pituitary samples and cell culture}

A total of 119 pituitary adenoma samples removed by transsphenoidal resection were included in this study: 34 from patients showing GH-secreting tumors and acromegaly with elevated serum $\mathrm{GH}$ and/or insulin-like growth factor 1 levels; 19 from patients presenting prolactin (PRL)-secreting adenomas with elevated serum PRL levels; 20 ACTH-secreting pituitary tumors causing Cushing's disease; 2 TSH-omas, and 45 samples from patients screened out as having clinically nonfunctioning adenomas with no evidence of hormone hypersecretion. Samples from local Hospitals were immediately transferred to sterile cold $\left(4^{\circ} \mathrm{C}\right)$ culture medium (DMEM). Under sterile conditions, each sample was minced into $1-2 \mathrm{~mm}^{3}$ pieces, and two to five of them were snap frozen in liquid nitrogen for posterior RNA isolation. When possible, remaining tissue pieces were processed as previously described (16).

For measurements of $\left[\mathrm{Ca}^{2+}\right]_{\mathrm{i}}, 50000$ dispersed cells/coverslip were plated in $10 \%$ serum containing medium. For apoptosis determination experiments, 30000 to 50000 cells/culture dish were seeded. Medium was freshly replaced every $48 \mathrm{~h}$.

\section{KISS1 and KISS1R expression in pituitary samples}

Expression of KISS1 and KISS1R were analyzed in 119 adenomatous pituitary fragments and additionally in 2 normal pituitary tissues obtained from different commercial sources (Clontech and CliniSciences, Montrouge, France). Total RNA was isolated using Trizol reagent (Invitrogen) as recommended by the manufacturer's instructions. RNA was reverse transcribed to cDNA by using PowerScript (BD Bioscience, Erembodegem, Belgium) reverse transcriptase following the manufacturer's manual. PCR analysis was employed to assess the expression of KISS1 (GenBank accession no. NM_002256), and its receptor KISS1R (GenBank accession no. NM_032551) was assessed by using an iCycler IQ thermocycler (Bio-Rad). Temperature profiles were as follows: $94{ }^{\circ} \mathrm{C} / 15 \mathrm{~s}, 65^{\circ} \mathrm{C} / 15 \mathrm{~s}$, and $72{ }^{\circ} \mathrm{C} / 15 \mathrm{~s}$ for 35 cycles. PCR products were electrophoresed in $2 \%$ agarose gel containing ethidium bromide and extracted using QIAQuick Gel Extraction kit (Qiagen). Identities of amplicons were confirmed by sequencing at University Facilities. To control the integrity of RNA and the efficiency of the RT reaction, the expression of $18 \mathrm{~S}$ was determined in each sample.

\section{Measurement of free cytosolic calcium concentration $\left(\left[\mathrm{Ca}^{2+}\right]_{i}\right)$ in single cells}

The effect of kisspetin-10 administration on $\left[\mathrm{Ca}^{2+}\right]_{\mathrm{i}}$ kinetics in single adenomatous pituitary cells in culture was evaluated using a microfluorimetric technique previously described in detail (16), in which kisspeptin-10 was administered through pipette ejection (16) and its effect on $\left[\mathrm{Ca}^{2+}\right]_{\mathrm{i}}$. was measured every $5 \mathrm{~s}$ by using MetaFluor Software (Imaging Corporation, West Chester, PA, USA). 


\section{Immunofluorescence}

Primary cultured pituitary adenoma cells (20 000/well) were seeded in 8-well chamber slides (Lab-Tek Chamber Slide System, Nalgene Nunc International, Naperville, IL, USA) and incubated for $30 \mathrm{~min}$ in a humidified atmosphere at $37^{\circ} \mathrm{C}$ with a rabbit anti-human GPR54 antibody (1:100; MBL International Corporation, Woburn, MA, USA). The cells were then fixed in methanol-acetone $(1: 1)$ for $10 \mathrm{~min}$ at $-20{ }^{\circ} \mathrm{C}$, blocked for $1 \mathrm{~h}$ with a blocking buffer ( $5 \%$ goat serum in PBS), and incubated with a secondary FITC-conjugated goat anti-rabbit antibody for $45 \mathrm{~min}$ at room temperature. Slides were then mounted, visualized, and photographed as previously reported (17). Preimmune serum and antigen-adsorbed antibody were used as controls of antibody specificity.

\section{DAPI staining}

Cells were grown in $35 \mathrm{~mm}$ diameter culture dish at a seeding density of 30000 to 50000 cells/dish in DMEM $+10 \%$ FCS for $24 \mathrm{~h}$ prior treatment. The day of the experiment, cells were washed and treated with kisppeptin-10 $\left(10^{-6}, 10^{-7}\right.$, and $\left.10^{-9} \mathrm{M}\right)$ for 12,24 , or $48 \mathrm{~h}$ in DMEM $+0.5 \%$ FCS. Following, adenomatous cells were fixed in Bouin's solution for $30 \mathrm{~min}$, and then stained with $1 \mu \mathrm{g} / \mathrm{ml}$ DAPI for $30 \mathrm{~min}$. Treatments were randomly examined by an operator in a blind manner at $40 \times$ magnification in a fluorescence microscope (Zeiss) at $340-380 \mathrm{~nm}$ light intensity. Apoptotic cells were characterized by chromatin condensation and fragmentation, whereas cells considered as normal exhibited a typical morphology with smooth nuclear and cellular membranes (18).

\section{Results}

\section{KISS1 and KISS1R expression in pituitary samples}

PCR amplification of KISS1 gave the expected fragment size of 119 bp in $35.5 \%$ of NFPA ( 16 out of 45 ), in $35 \%$ of corticotrope adenomas ( 7 out of 20 ), in $38.24 \%$ of GH-producing adenomas (13 out of 34), and in $47.37 \%$ of prolactinomas tested (9 out of 19; Fig. 1B-E). DNA sequencing of the purified band confirmed the identity of the amplified transcripts, thus demonstrating that KISS1 is expressed in the above-mentioned pituitary tumors. Furthermore, KISS1R transcript was expressed in $51.1 \%$ of NFPA $(23 / 45)$, in $40 \%$ of corticotrope adenomas $(8 / 20)$, in $41.18 \%$ of GH-producing adenomas $(14 / 34)$, and in $57.89 \%$ of tested prolactinomas (11/19; Fig. 1B-E). The amplified product presented the expected size for the KISS1R cDNA fragment (198 bp), and the nucleotide sequence matched the published sequence for the respective human KISS1R.
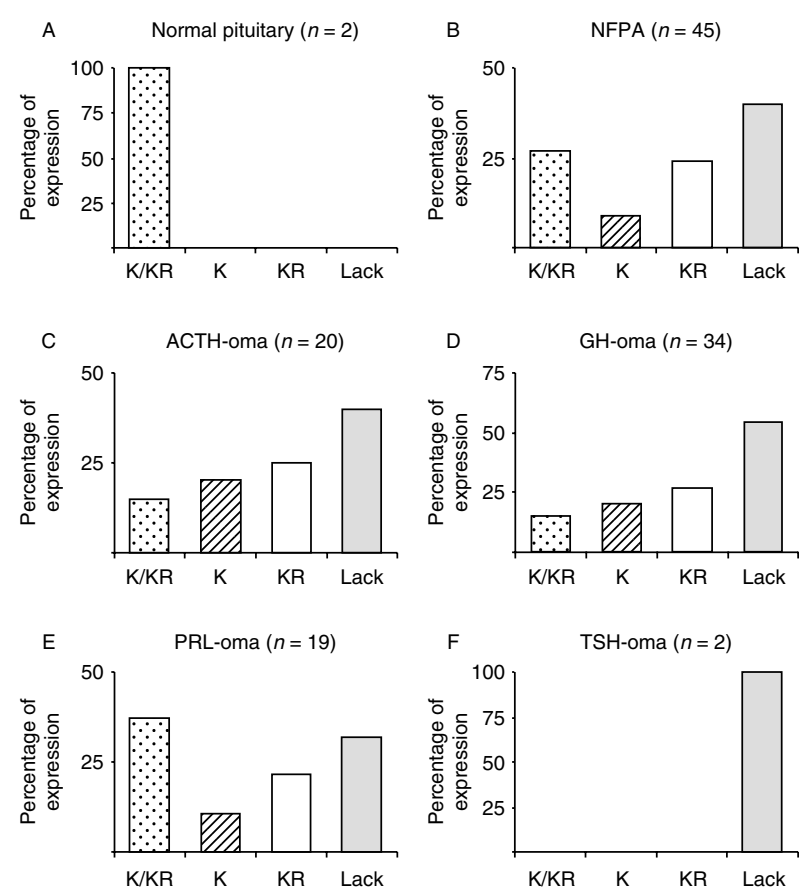

Figure $1 K I S S 1$ and KISS1R expression profile in normal and different adenomatous pituitaries. Each panel illustrates the percentage of samples expressing KISS1 (K), KISS1R (KR), $K I S S 1$ and $K I S S 1 R$ simultaneously $(K / K R)$ and the absence of both $K I S S 1$ and KISS1R transcripts (lack), respectively, from 2 normal pituitary samples, 45 NFPA, 20 ACTH-omas, 34 GH-omas, 19 PRL-omas and 2 TSH-omas.

As shown in Fig. 1A, KISS1 and KISS1R transcripts were expressed simultaneously in normal pituitary samples. Similar synchronized expression of both transcripts was also confirmed in $26.6 \%$ of studied NFPA (12 out of 45 ), in 15\% of corticotrope adenomas $(3 / 20)$, in $14.7 \%$ of $\mathrm{GH}$-producing adenomas (4/34), and in $37 \%$ of prolactinomas (7/19). Thus, the vast majority of pituitary tumors studied lacked simultaneous expression of KISS1 and KISS1R (Fig. 1B-E). Particularly, in $40 \%$ of NFPA (18/45), in $40 \%$ of ACTHproducing adenomas $(8 / 20)$, in $38.2 \%$ of $\mathrm{GH}$-producing adenomas (13/34), and in 31\% of PRL-secreting tumors $(6 / 19)$, the concomitant expression of both KISS1 and KISS1R transcripts is defective. Additionally, we include two cases of TSH-producing adenomas in which KISS1 and KISS1R transcripts were completely absent (Fig. 1F). Statistical comparison using a $\chi^{2}$ method indicated that the frequency distribution patterns of KISS1/KISS1R expression displayed by the different types of pituitary adenomas differ significantly.

A basic set of information regarding patient age, gender, tumor size and recurrence, as well as KISS1 and KISS1R expression could be collected in 89 out of the 119 cases studied, and has been included in Supplementary Table 1, see section on supplementary data given at the end of this article. Analysis of the data 
collected did not reveal any apparent association between these parameters and KISS1/KISS1R expression.

\section{Measurement of $\left[\mathrm{Ca}^{2+}\right]_{i}$ in single cells}

$\left[\mathrm{Ca}^{2+}\right]_{\mathrm{i}}$ was evaluated in cells derived from five different GH-producing adenomas in which KISS1R expression was previously confirmed by PCR analysis. A prominent, significant rise in $\left[\mathrm{Ca}^{2+}\right]_{\mathrm{i}}$ in response to kisspeptin administration was observed in cells from four of them. A detailed analysis of $\left[\mathrm{Ca}^{2+}\right]_{\mathrm{i}}$ recordings from all responsive cells $(n=71$ cells), showed that $1 \mu \mathrm{M}$ kisspeptin induced a biphasic increase in $\left[\mathrm{Ca}^{2+}\right]_{\mathrm{i}}$ in GH-producing cells (Fig. 2A). This response was characterized by a rapid and prominent $\left[\mathrm{Ca}^{2+}\right]_{\mathrm{i}}$ spike that gradually declined to near-basal levels. In contrast, the percentage of cells that responded to kisspeptin administration with a rise in $\left[\mathrm{Ca}^{2+}\right]_{\mathrm{i}}$ was variable among the four different examined cases (Fig. 2A inset). Quantitative analysis of different parameters that characterize the response to kisspeptin-10 administration reveals that all cases showed a similar $\left[\mathrm{Ca}^{2+}\right]_{\mathrm{i}}$ increment as well as a comparable time to reach the maximal response (Fig. 2A inset).

On the other hand, cultured cells derived from NFPA in which KISS1R expression was previously demonstrated by RT-PCR did not respond to kisspeptin administration with changes in their $\left[\mathrm{Ca}^{2+}\right]_{\mathrm{i}}$ basal levels. Immunocytochemical staining of KISS1R on individual adenomatous pituitary-derived cells using fluorescent secondary antibody demonstrated its localization at the plasma membrane level, thus confirming the presence of KISS1R on studied cells (Fig. 2B).

\section{Apoptotic rate in pituitary tumors upon kisspeptin administration}

The effect of kisspeptin-10 on apoptosis was tested in cultured cells derived from NFPA and GH-producing adenomas expressing KISS1R. In NFPA, 12, 24, and $48 \mathrm{~h}$ incubation with increasing doses of kisspeptin-10 $\left(10^{-9}\right.$ to $\left.10^{-6} \mathrm{M}\right)$ were tested. After $12 \mathrm{~h}$ incubation in the presence of $10^{-6} \mathrm{M}$ kisspeptin-10, a significant increase in the number of apoptotic adenomatous cells was observed (Fig. 3). Such effect was also noticeable after $24 \mathrm{~h}$ treatment with all kisspeptin doses tested. In contrast, no significant effect of kisspeptin-10 after $48 \mathrm{~h}$ treatment was observed for any of the evaluated doses on NFPA-derived cells (Fig. 3A). On the other hand, in GH-producing adenomatous cells, $24 \mathrm{~h}$ incubation with $10^{-6} \mathrm{M}$ kisspeptin-10 elicited a significant increase in the number of apoptotic cells (Fig. 3B). As can be observed in a representative micrograph, several cultured adenomatous cells exposed to $10^{-6} \mathrm{M}$ kisspeptin-10 for $24 \mathrm{~h}$ showed the typical DNA fragmentation that occurs during apoptosis as evidenced by DAPI staining (Fig. 3D).
A

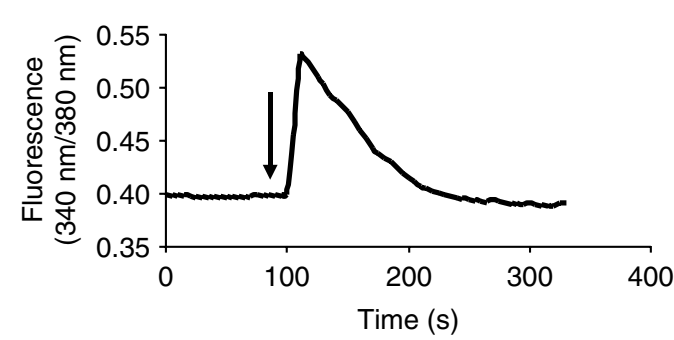

\begin{tabular}{|c|c|c|c|}
\hline Case & Responsive cells (\%) & Maximal increase (\%) & Time (s) \\
\cline { 2 - 4 } JA-0702 & 47 & $135.28 \pm 2.07$ & $30.5 \pm 3.8$ \\
JA-0202 & 22 & $158.77 \pm 35.48$ & $16.8 \pm 4.98$ \\
JA-0303 & 65.8 & $130.6 \pm 2.31$ & $46.96 \pm 2.98$ \\
JA-0504 & 42 & $140.13 \pm 9.78$ & $46.42 \pm 6.6$ \\
\hline
\end{tabular}

B
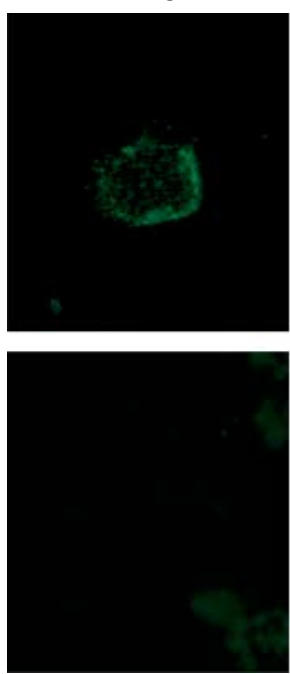

U.V.
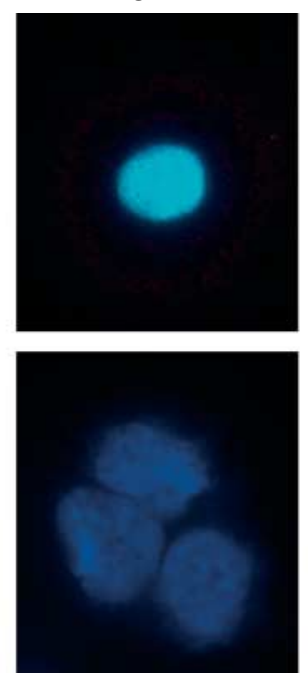

U.V. + visible
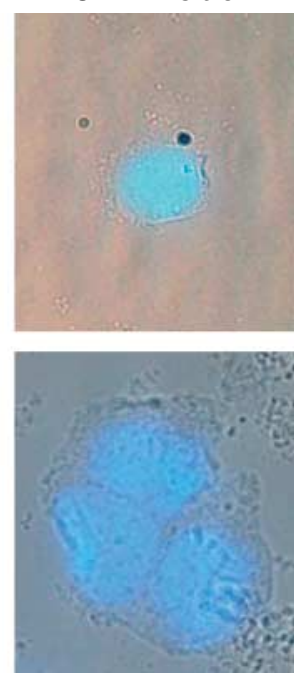

Figure 2 (A) Representative profile of the $\left[\mathrm{Ca}^{2+}\right]_{i}$ kinetics observed in response to $1 \mu \mathrm{M}$ kisspeptin-10 treatment (arrow) in single adenomatous somatotropes obtained from Case JA-0702. The table below illustrates the percentage of kisspeptin-responsive tumor somatotrope cells, the $\left[\mathrm{Ca}^{2+}\right]_{i}$ maximal increase, and the time to reach the maximal rise in every studied case. (B) Primary cultured NFPA cells $\left(2 \times 10^{4} /\right.$ well) were incubated with the specific KISS1R antibody, fixed, incubated with the secondary FITC-conjugated antibody, mounted with the antifade containing reagent, and photographed with a $60 \times$ magnification objective. FITC, NFPA cells observed with the FITC filter, revealing KISS1R immunofluorescence; u.v., NFPA cells observed with the u.v. filter, revealing nuclear immunofluorescence; u.v. + visible: merged u.v. and visible images. 
A

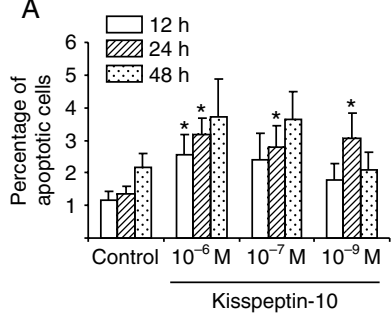

C

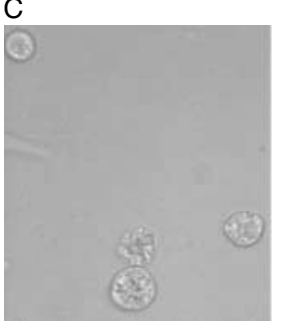

B

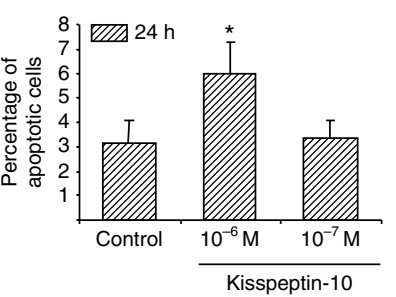

D

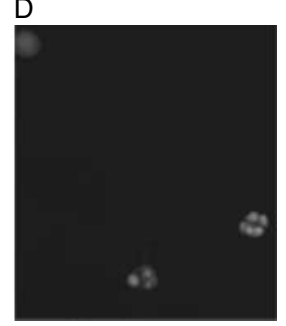

Figure 3 ( A and B) The time (12, 24, and $48 \mathrm{~h}$ ) and dose $\left(10^{-6}, 10^{-7}\right.$, and $\left.10^{-9} \mathrm{M}\right)$ effects of kisspeptin-10 on apoptotic rate of human NFPA and GH-producing cultured cells, respectively, are shown. Tumor cells were cultured in vitro in the absence (control) or presence of kisspeptin-10. One thousand cells were randomly counted per treatment and determined to be normal or apoptotic upon morphological characteristics. Results are expressed as percentage of apoptotic cells (mean \pm S.E.M.) from at least seven and a maximum of ten NFPA tumors and from at least three somatotropinomas. ${ }^{\star} P<0.05$, compared with control.

( $C$ and $D)$ Representative micrograph of apoptotic cells derived from pituitary tumor exposed to $10^{-6} \mathrm{M}$ kisspeptin-10 for $24 \mathrm{~h}$. Arrows indicate apoptotic cells in which chromatin condensation/ nuclear fragmentation has been induced by kisspeptin treatment.

\section{Discussion}

Earlier reports showed that the KISS1/KISS1R system plays an important role in tumor progression in a wide variety of tumor types (reviewed in (19)). More recently, its presence at the pituitary level and its direct action on adenohypophysial hormone release have been demonstrated in several species $(14,20,21)$. However, to date, the presence and potential role of the KISS1/KISS1R system in pituitary adenomas has not been reported yet. Our present data show an altered expression of genes encoding kisspeptin and its receptor in different types of pituitary adenomas, which contrasts to their concomitant expression in normal human pituitary. Furthermore, we provide evidence on functional responses elicited by kisspeptin in cultured adenomatous pituitary cells, in which kisspeptin-10 directly acts on GH-producing adenomatous cells by increasing $\left[\mathrm{Ca}^{2+}\right]_{\mathrm{i}}$ and by inducing apoptosis in KISS1R-expressing pituitary tumors.

A compelling body of evidence indicates that the participation of KISS1/KISS1R tandem is critical for the neuroendocrine regulation of reproduction, primarily acting through GNRH secretion at the hypothalamus $(11,12,22,23)$. Although initial reports documented

high KISS1R levels at the pituitary (3-5), its putative physiological roles as well as those of their natural ligands, kisspeptins, in this gland have remained elusive and focus of speculation. Recently, our group and others demonstrated that kisspeptins also act directly at the pituitary level by releasing both LH and $\mathrm{GH}(14,20,21)$, thus offering new evidence to understand the functional significance of the reported presence of KISS1R at the pituitary, where it is also accompanied by the expression of its ligands $(14,24)$. Furthermore, on the basis of data from gene expression analyses on pituitary as well as direct functional responses at both the individual and population cell level, there is now evidence suggestive that KISS1/KISS1R system is not only involved in the control of gonadotropes, but can also regulate somatotropes, thereby expanding the potential neuroendocrine functions for this neuropeptide system $(5,14,25)$. In this context, the concomitant expression of both KISS1 and KISS1R transcripts in normal pituitary samples reported herein further substantiates the contention that autocrine and/or paracrine interactions of kisspeptin and its receptor may occur in normal human pituitary gland, similar to that previously documented for KISS1/KISS1R system in an invasive tissue as placenta (4) and in papillary cancers (26).

Interestingly, expression of KISS1 and KISS1R is altered in pituitary adenomas, with a high proportion of them being defective in the simultaneous expression of both transcripts. This partial or complete loss of expression of the KISS1/KISS1R system in pituitary adenomas suggests that a functional involvement of these genes in the etiology of pituitary tumors should not be discarded, as it has been reported elsewhere for several neuropeptides as galanin, neurotensin, vasopressin, and cholecystokinin $(27,28)$. Likewise, expression levels of somatostatin receptors often show pathophysiologically relevant alterations in pituitary tumors (29), and it will be of interest to analyze the possible relationship between these two inhibitory systems, KISS1/KISS1R and somatostatin/somatostatin receptors, at the pituitary level, especially in GH adenomas. In line with this, although the precise relevance and underlying mechanism of the uneven expression of KISS1/KISS1R in human pituitary adenomas are yet to be elucidated, it is not unreasonable to propose that understanding the impaired expression of this molecular tandem may result, in the future, of therapeutic or clinical relevance in the outcome of patients with pituitary adenomas, as it has been already anticipated in several malignancies, including melanoma $(30,31)$, carcinoma of the ovary (32), stomach (33), urinary bladder (34), and esophagus (35). In support of this view, our present results are indicating that all the required elements for the KISS1/KISS1R system to be functional are in place in the human pituitary.

To the best of our knowledge, the present study is the first to characterize one of the elements of the signaling 
pathway triggered by KISS1R upon kisspeptin-10 administration in single cultured adenomatous cells. Specifically, kisspeptin-10 administration elicited a rapid and prominent $\left[\mathrm{Ca}^{2+}\right]_{\mathrm{i}}$ increase in $\mathrm{GH}$-producing adenoma cells. Previous studies have shown that metastin and shorter kisspeptin forms induce a potent and specific increase in $\left[\mathrm{Ca}^{2+}\right]_{\mathrm{i}}$ in different types of cells (36), including cell lines transfected with KISS1R as CHO-K1 cells (5), HEK293 (4), Cos-7 cells (37), human trophoblasts (38), cultured hippocampal neurons (25), and in primary rat gonadotropes and somatotropes (14). Our present data provide strong evidence that kisspeptin-10 directly acts on human GH-producing adenomatous cells by increasing $\left[\mathrm{Ca}^{2+}\right]_{\mathrm{i}}$, a well-known, pivotal second messenger directly and necessarily linked to hormone release $(39,40)$. Perhaps the tight link between $\mathrm{Ca}^{2+}$ signaling and secretion may help explain the unique lack of response shown by the studied NFPAs in terms of $\left[\mathrm{Ca}^{2+}\right]_{\mathrm{i}}$ dynamics, in that these type of tumors are often refractory to stimulation and hardly respond to releasing factors by secreting significant levels of hormones, as opposed of the intrinsic sensitivity of GH-producing adenomas, which secrete massive $\mathrm{GH}$ levels in response to an exogenous stimulus most often via $\mathrm{Ca}^{2+}$ signaling.

Of note, however, our data reveal that the functional capacity of the KISS1/KISS1R system in pituitary adenomas is not restricted to $\mathrm{Ca}^{2+}$ signaling, but can be associated to a more clinically relevant process in these tumors, i.e. apoptosis. Indeed, it is known that pituitary tissue homeostasis results from the balance between cell proliferation and programmed cell death or apoptosis. Consequently, the impairment in cell death mechanisms derives in tumor genesis and progression (41). In the present work, we analyzed the potential effect of kisspeptin administration on the apoptotic rate in KISS1R-expressing pituitary adenomas, particularly on GH-producing and NFPA. This revealed that kisspeptin-10 exposure for 12 or $24 \mathrm{~h}$ (for NFPA) or $24 \mathrm{~h}$ (for GH-producing adenomas) caused a significant increase in the number of apoptotic cells. Thus, the ability of kisspeptin-10 to induce apoptosis shown here, coupled to the reported evidence for increased basal level of apoptosis following KISS1R activation described in other cell systems as human mammary carcinoma cell line (42), HEK293 or Jurkat cells (43), and in light of the originally documented metastasis inhibiting properties of KISS1 gene (3), makes the KISS1/KISS1R tandem an attractive target for drug design and research, as a potential new therapeutic target for the management of certain pituitary adenomas.

In summary, our results provide evidence that the expression pattern of the KISS1/KISS1R system is distinctly altered in pituitary adenomas; also, that kisspeptins directly stimulate $\mathrm{Ca}^{2+}$ signaling in $\mathrm{GH}-$ producing adenoma cells; and finally, that kisspeptins augment apoptotic rate in cells from both GH-producing and NFPA. These findings emphasize the importance of developing additional studies to attain a more complete understanding of the KISS1/KISS1R system, their gene products, and functional capacities as a new, potentially relevant player in normal human pituitary and in pituitary adenomas.

\section{Supplementary data}

This is linked to the online version of the paper at http://dx.doi.org/ 10.1530/EJE-10-0905.

\section{Declaration of interest}

The authors declare that there is no conflict of interest that could be perceived as prejudicing the impartiality of the research reported.

\section{Funding}

This work was supported by grants from Junta de Andalucía (BIO0139. CTS-01705, and CTS-5051) and Ministerio de Ciencia e Innovación/FEDER (BFU2007-60180/BFI, BFU2008-01136-BFI, and RYC-2007-00186). CIBER de Fisiopatología de la Obesidad y Nutrición and CIBERER are initiatives of Instituto de Salud Carlos III.

\section{References}

1 Ezzat S, Asa SL, Couldwell WT, Barr CE, Dodge WE, Vance ML \& McCutcheon IE. The prevalence of pituitary adenomas: a systematic review. Cancer 2004101 613-619. (doi:10.1002/ cncr.20412)

2 Yeh PJ \& Chen JW. Pituitary tumors: surgical and medical management. Surgical Oncology 19976 67-92. (doi:10.1016/ S0960-7404(97)00008-X)

3 Ohtaki T, Shintani Y, Honda S, Matsumoto H, Hori A, Kanehashi K, Terao Y, Kumano S, Takatsu Y, Masuda Y, Ishibashi Y, Watanabe T, Asada M, Yamada T, Suenaga M, Kitada C, Usuki S, Kurokawa T, Onda H, Nishimura O \& Fujino M. Metastasis suppressor gene KiSS-1 encodes peptide ligand of a G-protein-coupled receptor. Nature 2001411 613-617. (doi:10. 1038/35079135)

4 Muir AI, Chamberlain L, Elshourbagy NA, Michalovich D, Moore DJ, Calamari A, Szekeres PG, Sarau HM, Chambers JK, Murdock P, Steplewski K, Shabon U, Miller JE, Middleton SE, Darker JG, Larminie CG, Wilson S, Bergsma DJ, Emson P, Faull R, Philpott KL \& Harrison DC. AXOR12, a novel human G proteincoupled receptor, activated by the peptide KiSS-1. Journal of Biological Chemistry 2001276 28969-28975. (doi:10.1074/jbc. M102743200)

5 Kotani M, Detheux M, Vandenbogaerde A, Communi D, Vanderwinden JM, Le Poul E, Brezillon S, Tyldesley R, SuarezHuerta N, Vandeput F, Blanpain C, Schiffmann SN, Vassart G \& Parmentier M. The metastasis suppressor gene KiSS-1 encodes kisspeptins, the natural ligands of the orphan $\mathrm{G}$ protein-coupled receptor GPR54. Journal of Biological Chemistry $20012 \mathbf{2 7 6}$ 34631-34636. (doi:10.1074/jbc.M104847200)

6 Lee JH, Miele ME, Hicks DJ, Phillips KK, Trent JM, Weissman BE \& Welch DR. KiSS-1, a novel human malignant melanoma metastasis-suppressor gene. Journal of the National Cancer Institute 199688 1731-1737. (doi:10.1093/jnci/88.23.1731)

7 Lee JH \& Welch DR. Identification of highly expressed genes in metastasis-suppressed chromosome 6/human malignant melanoma hybrid cells using subtractive hybridization and differential display. International Journal of Cancer $1997 \mathbf{7 1} 1035-1044$. (doi:10.1002/(SICI)1097-0215(19970611)71:6<1035::AID-IJC $20>3.0 .(0 ; 2-B)$ 
8 West A, Vojta PJ, Welch DR \& Weissman BE. Chromosome localization and genomic structure of the KiSS-1 metastasis suppressor gene (KISS1). Genomics 199854 145-148. (doi:10. 1006/geno.1998.5566)

9 Harms JF, Welch DR \& Miele ME. KISS1 metastasis suppression and emergent pathways. Clinical and Experimental Metastasis 200320 11-18. (doi:10.1023/A:1022530100931)

10 Nash KT, Phadke PA, Navenot JM, Hurst DR, Accavitti-Loper MA, Sztul E, Vaidya KS, Frost AR, Kappes JC, Peiper SC \& Welch DR. Requirement of KISS1 secretion for multiple organ metastasis suppression and maintenance of tumor dormancy. Journal of the National Cancer Institute 200799 309-321. (doi:10.1093/jnci/ djk053)

11 de Roux N, Genin E, Carel JC, Matsuda F, Chaussain JL \& Milgrom E. Hypogonadotropic hypogonadism due to loss of function of the KiSS1-derived peptide receptor GPR54. PNAS 2003100 10972-10976. (doi:10.1073/pnas.1834399100)

12 Seminara SB, Messager S, Chatzidaki EE, Thresher RR, Acierno JS Jr, Shagoury JK, Bo-Abbas Y, Kuohung W, Schwinof KM, Hendrick AG, Zahn D, Dixon J, Kaiser UB, Slaugenhaupt SA, Gusella JF, O’Rahilly S, Carlton MB, Crowley WF Jr, Aparicio SA \& Colledge WH. The GPR 54 gene as a regulator of puberty. New England Journal of Medicine 2003349 1614-1627. (doi:10.1056/ NEJMoa035322)

13 Roa J, Castellano JM, Navarro VM, Handelsman DJ, Pinilla L \& Tena-Sempere M. Kisspeptins and the control of gonadotropin secretion in male and female rodents. Peptides 200930 57-66. (doi:10.1016/j.peptides.2008.08.009)

14 Gutierrez-Pascual E, Martinez-Fuentes AJ, Pinilla L, TenaSempere M, Malagon MM \& Castaño JP. Direct pituitary effects of kisspeptin: activation of gonadotrophs and somatotrophs and stimulation of luteinising hormone and growth hormone secretion. Journal of Neuroendocrinology $2007 \quad 19$ 521-530. (doi:10.1111/j.1365-2826.2007.01558.x)

15 Richard N, Corvaisier S, Camacho E \& Kottler ML. KiSS-1 and GPR 54 at the pituitary level: overview and recent insights. Peptides 200930 123-129. (doi:10.1016/j.peptides.2008.09.015)

16 Martinez-Fuentes AJ, Moreno-Fernandez J, Vazquez-Martinez R, Duran-Prado M, de la Riva A, Tena-Sempere M, Dieguez C, Jimenez-Reina L, Webb SM, Pumar A, Leal-Cerro A, Benito-Lopez P, Malagon MM \& Castano JP. Ghrelin is produced by and directly activates corticotrope cells from adrenocorticotropin-secreting adenomas. Journal of Clinical Endocrinology and Metabolism 2006 91 2225-2231. (doi:10.1210/jc.2006-0235)

17 Zatelli MC, Minoia M, Filieri C, Tagliati F, Buratto M, Ambrosio MR, Lapparelli M, Scanarini M \& Degli Uberti EC. Effect of everolimus on cell viability in nonfunctioning pituitary adenomas. Journal of Clinical Endocrinology and Metabolism 2010 95 968-976. (doi:10.1210/jc.2009-1641)

18 Deguil J, Jailloux D, Page G, Fauconneau B, Houeto JL, Philippe M, Muller JM \& Pain S. Neuroprotective effects of pituitary adenylate cyclase-activating polypeptide (PACAP) in MPP +-induced alteration of translational control in Neuro-2a neuroblastoma cells. Journal of Neuroscience Research 2007 85 2017-2025. (doi:10. 1002/jnr.21318)

19 Makri A, Pissimissis N, Lembessis P, Polychronakos C \& Koutsilieris M. The kisspeptin (KiSS-1)/GPR 54 system in cancer biology. Cancer Treatment Reviews 2008 34 682-692. (doi:10. 1016/j.ctrv.2008.05.007)

20 Suzuki S, Kadokawa H \& Hashizume T. Direct kisspeptin-10 stimulation on luteinizing hormone secretion from bovine and porcine anterior pituitary cells. Animal Reproduction Science 2008 103 360-365. (doi:10.1016/j.anireprosci.2007.05.016)

21 Kadokawa H, Suzuki S \& Hashizume T. Kisspeptin-10 stimulates the secretion of growth hormone and prolactin directly from cultured bovine anterior pituitary cells. Animal Reproduction Science $2008 \mathbf{1 0 5}$ 404-408. (doi:10.1016/j.anireprosci.2007. $11.005)$

22 Murphy KG. Kisspeptins: regulators of metastasis and the hypothalamic-pituitary-gonadal axis. Journal of Neuroendocrinology 200517 519-525. (doi:10.1111/j.1365-2826.2005.01328.x)
23 Seminara SB. Metastin and its G protein-coupled receptor, GPR 54: critical pathway modulating GnRH secretion. Frontiers in Neuroendocrinology $2005 \mathbf{2 6}$ 131-138. (doi:10.1016/j.yfrne. 2005.10.001)

24 Kinoshita M, Tsukamura H, Adachi S, Matsui H, Uenoyama Y, Iwata K, Yamada S, Inoue K, Ohtaki T, Matsumoto H \& Maeda K. Involvement of central metastin in the regulation of preovulatory luteinizing hormone surge and estrous cyclicity in female rats. Endocrinology 2005 1464431-4436. (doi:10.1210/en.2005-0195)

25 Brailoiu GC, Dun SL, Ohsawa M, Yin D, Yang J, Chang JK, Brailoiu E \& Dun NJ. KiSS-1 expression and metastin-like immunoreactivity in the rat brain. Journal of Comparative Neurology 2005 481 314-329. (doi:10.1002/cne.20350)

26 Ringel MD, Hardy E, Bernet VJ, Burch HB, Schuppert F, Burman KD \& Saji M. Metastin receptor is overexpressed in papillary thyroid cancer and activates MAP kinase in thyroid cancer cells. Journal of Clinical Endocrinology and Metabolism 2002 87 2399. (doi:10.1210/jc.87.5.2399)

27 Seufferlein T \& Rozengurt E. Galanin, neurotensin, and phorbol esters rapidly stimulate activation of mitogen-activated protein kinase in small cell lung cancer cells. Cancer Research 199656 5758-5764.

28 Ormandy CJ, Lee CS, Ormandy HF, Fantl V, Shine J, Peters G \& Sutherland RL. Amplification, expression, and steroid regulation of the preprogalanin gene in human breast cancer. Cancer Research 199858 1353-1357.

29 Taboada GF, Luque RM, Bastos W, Guimarães RF, Marcondes JB, Chimelli LM, Fontes R, Mata PJ, Filho PN, Carvalho DP, Kineman RD \& Gadelha MR. Quantitative analysis of somatostatin receptor subtype (SSTR1-5) gene expression levels in somatotropinomas and non-functioning pituitary adenomas. European Journal of Endocrinology $2007 \mathbf{1 5 6}$ 65-74. (doi:10.1530/eje.1. 02313)

30 Shirasaki F, Takata M, Hatta N \& Takehara K. Loss of expression of the metastasis suppressor gene KiSS1 during melanoma progression and its association with $\mathrm{LOH}$ of chromosome 6q16.3-q23. Cancer Research $2001617422-7425$.

31 Martins CM, Fernandes BF, Antecka E, Di Cesare S, Mansure JJ, Marshall JC \& Burnier MN Jr. Expression of the metastasis suppressor gene KISS1 in uveal melanoma. Eye 200822 707-711. (doi:10.1038/sj.eye.6703090)

32 Prentice LM, Klausen C, Kalloger S, Kobel M, McKinney S, Santos JL, Kenney C, Mehl E, Gilks CB, Leung P, Swenerton K, Huntsman DG \& Aparicio SA. Kisspeptin and GPR54 immunoreactivity in a cohort of 518 patients defines favourable prognosis and clear cell subtype in ovarian carcinoma. BMC Medicine 2007 5 33. (doi:10.1186/1741-7015-5-33)

33 Dhar DK, Naora H, Kubota H, Maruyama R, Yoshimura H, Tonomoto Y, Tachibana M, Ono T, Otani H \& Nagasue N. Downregulation of KiSS-1 expression is responsible for tumor invasion and worse prognosis in gastric carcinoma. International Journal of Cancer 2004111 868-872. (doi:10.1002/ijc.20357)

34 Sanchez-Carbayo M, Capodieci P \& Cordon-Cardo C. Tumor suppressor role of KiSS-1 in bladder cancer: loss of KiSS-1 expression is associated with bladder cancer progression and clinical outcome. American Journal of Pathology $2003 \mathbf{1 6 2}$ 609-617.

35 Ikeguchi M, Yamaguchi K \& Kaibara N. Clinical significance of the loss of KiSS-1 and orphan G-protein-coupled receptor (hOT7T175) gene expression in esophageal squamous cell carcinoma. Clinical Cancer Research $2004 \quad 10$ 1379-1383. (doi:10.1158/1078-0432.CCR-1519-02)

36 Castano JP, Martinez-Fuentes AJ, Gutierrez-Pascual E, Vaudry H, Tena-Sempere M \& Malagon MM. Intracellular signaling pathways activated by kisspeptins through GPR54: do multiple signals underlie function diversity? Peptides 200930 10-15. (doi:10.1016/j.peptides.2008.07.025)

37 Stafford LJ, Xia C, Ma W, Cai Y \& Liu M. Identification and characterization of mouse metastasis-suppressor KiSS1 and its G-protein-coupled receptor. Cancer Research 200262 5399-5404. 
38 Bilban M, Ghaffari-Tabrizi N, Hintermann E, Bauer S, Molzer S, Zoratti C, Malli R, Sharabi A, Hiden U, Graier W, Knofler M, Andreae F, Wagner O, Quaranta V \& Desoye G. Kisspeptin-10, a KiSS-1/metastin-derived decapeptide, is a physiological invasion inhibitor of primary human trophoblasts. Journal of Cell Science 2004117 1319-1328. (doi:10.1242/jcs.00971)

39 Stojilkovic SS, Izumi S \& Catt KJ. Participation of voltage-sensitive calcium channels in pituitary hormone release. Journal of Biological Chemistry 1988263 13054-13061.

40 Stojilkovic SS. $\mathrm{Ca}^{2+}$-regulated exocytosis and SNARE function. Trends in Endocrinology and Metabolism 200516 81-83. (doi:10. 1016/j.tem.2005.02.002)

41 Norbury CJ \& Zhivotovsky B. DNA damage-induced apoptosis. Oncogene 200423 2797-2808. (doi:10.1038/sj.onc.1207532)

42 Becker JA, Mirjolet JF, Bernard J, Burgeon E, Simons MJ, Vassart G, Parmentier M \& Libert F. Activation of GPR 54 promotes cell cycle arrest and apoptosis of human tumor cells through a specific transcriptional program not shared by other Gq-coupled receptors. Biochemical and Biophysical Research Communications 2005326 677-686. (doi:10.1016/j.bbrc.2004.11.094)

43 Navenot JM, Fujii N \& Peiper SC. Activation of Rho and Rhoassociated kinase by GPR 54 and KiSS1 metastasis suppressor gene product induces changes of cell morphology and contributes to apoptosis. Molecular Pharmacology 200975 1300-1306. (doi:10. 1124/mol.109.055095)

Received 2 December 2010

Accepted 17 December 2010 